\title{
A new species and new records of Paryphoconus from the Amazon region of Peru (Diptera: Ceratopogonidae)
}

\author{
Una nueva especie y nuevos registros de Paryphoconus de la región amazónica de Perú (Dip- \\ tera: Ceratopogonidae)
}

\author{
Melina Mauad ${ }^{1}$ and Gustavo R. Spinelli2* \\ IInstituto de Limnología "Dr. Raúl A. Ringuelet", Av. Calchaquí km. 23.5, 1888, Florencio Varela, Argentina. \\ ${ }^{2}$ División Entomología, Museo de La Plata, Paseo del Bosque, 1900 La Plata, Argentina. \\ *Correspondent: spinelli@fcnym.unlp.edu.ar
}

\begin{abstract}
Paryphoconus peruvianus, a new species from Peruvian Amazonia is described and illustrated from female and male specimens collected at light in the Department of Cuzco. The species is compared with its similar congener P. anomalicornis Kieffer. Furthermore, P. anomalicornis, $P$. fusciradialis Spinelli y Wirth and P. oliveirai Lane are firstly recorded from Peru.
\end{abstract}

Key words: Paryphoconus, new species, new records, Amazonia, Peru.

Resumen. Se describe e ilustra a Paryphoconus peruvianus, una especie nueva de la Amazonia peruana, a partir de hembras y machos capturados a la luz en el Departamento de Cuzco. Esta especie es comparada con su congénere más similar, P. anomalicornis Kieffer. Además, se registran por primera vez para Perú P. anomalicornis, P. fusciradialis Spinelli y Wirth y $P$. oliveirai Lane.

Palabras clave: Paryphoconus, nueva especie, nuevos registros, Amazonia, Perú.

\section{Introduction}

The Neotropical genus Paryphoconus Enderlein includes medium-sized to large (female wing lengths $1.5-7 \mathrm{~mm}$ ) predaceous midges frequently collected from near rivers in tropical and subtropical areas (Borkent and Spinelli, 2007). Spinelli and Wirth (1984) reviewed the genus, providing a key to females of 38 species and Spinelli (1998) described 2 additional species from northeastern Argentina. One of the species, $P$. sonorensis Wirth and Ratanaworabhan, reaches the Nearctic region.

Of the forty known species of the genus, the following 4 inhabit Peru: $P$. aemulus Macfie, $P$. angustipennis Enderlein, P. steineri Spinelli and Wirth, and $P$. terminalis (Coquillett) (Borkent and Spinelli, 2007). Our purpose is to describe a new species from the Department of Cuzco, as well as to present new distributional records for 3 species from the same

Recibido: 10 junio 2010; aceptado: 15 junio 2010 area and from Iquitos, another Amazonian area of the country.

\section{Materials and methods}

Specimens were collected placing a funnel approximately $20 \mathrm{~cm}$ in diameter above a jar of alcohol, close to a source of light, and were slide-mounted in Canada Balsam following the technique described by Borkent and Spinelli (2007). Illustrations were drawn with a camera lucida on a compound microscope.

For terminology, we followed the Manual of Nearctic Diptera (McAlpine et al., 1981). Terms for wing veins follow the system of the Manual of Nearctic Diptera, with modifications proposed by Szadziewski (1996). The holotype and the studied specimens are deposited in the Museo de La Plata, Argentina (MLPA), except for 2 paratypes ( 1 female, 1 male) that will be deposited in the Colección Nacional de Insectos of the Instituto de Biología, UNAM, Mexico. 

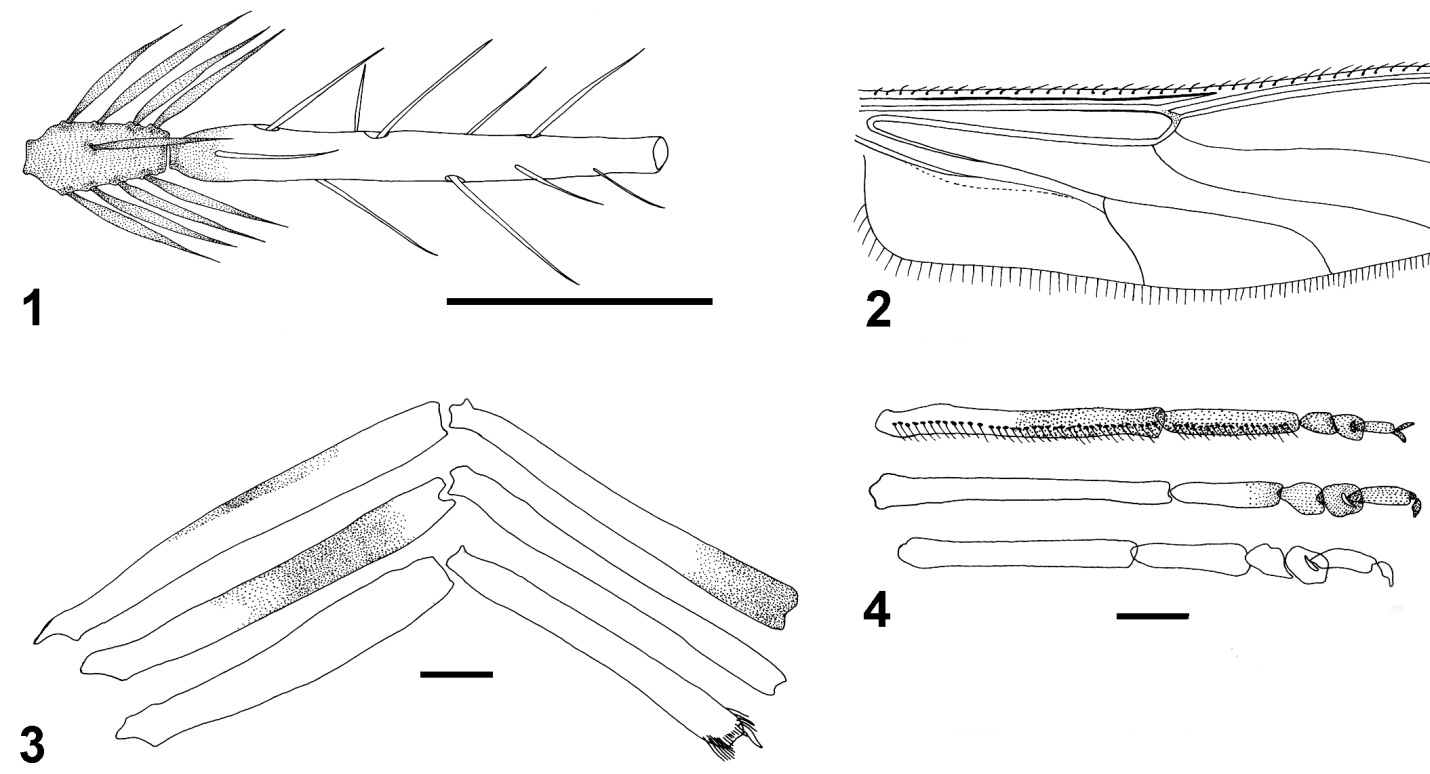

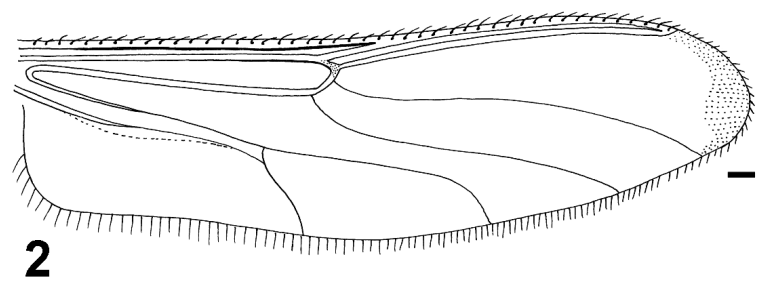

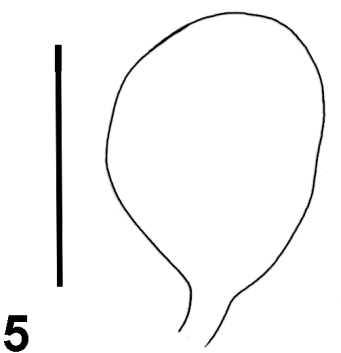

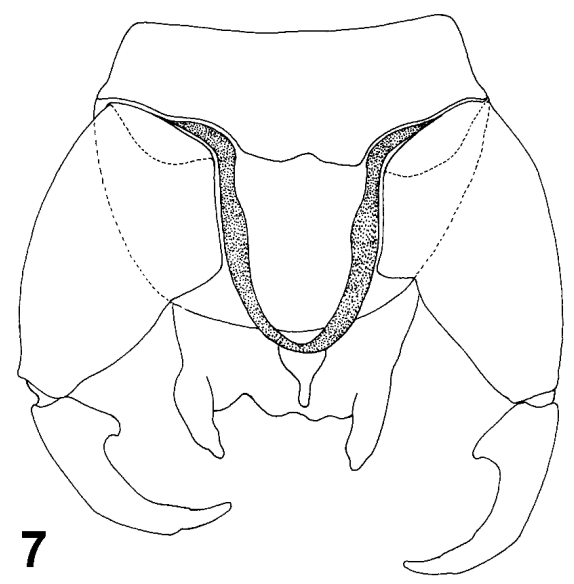

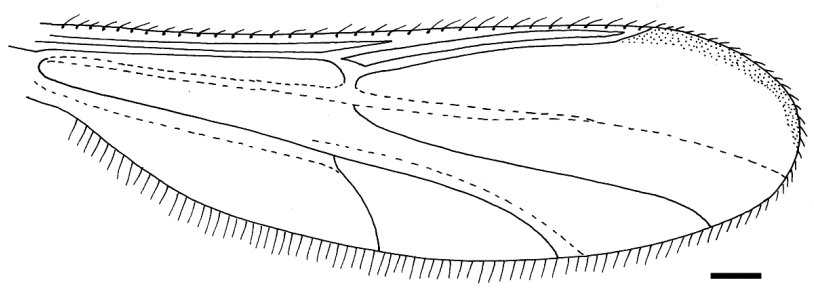

6

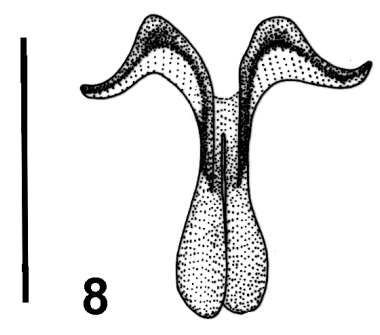

Figures 1-8. Paryphoconus peruvianus Mauad and Spinelli sp. n., adult. 1-5, holotype female; 6-8, allotype male. 1, Flagellomeres 8-9; 2, 6, wing; 3, femora and tibiae (top to bottom: hind, mid, fore); 4, tarsi (top to bottom: hind, mid, fore); 5, spermatheca; 7, genitalia (parameres removed); 8, parameres (scale bars $=0.05 \mathrm{~mm}$ ). 


\section{Description}

Paryphoconus peruvianus Mauad and Spinelli, sp. n. (Figs. 1-8)

Diagnosis. It is distinguished by the combination of the antenna with proximal flagellomeres dark with hastate setae and 5 distal flagellomeres whitish with fine setae, and wing membrane whitish hyaline only infuscated at apex, with its anal angle very well developed.

Female. Head dark brown except distal portion of clypeus and mouth parts yellowish brown. Flagellum with 8 proximal flagellomeres dark brown, bearing stout, dark brown hastate setae, 5 distal flagellomeres elongate, whitish to pale brown, with verticils and setae sparse and fine (Fig. 1); flagellomeres in proportion of 48-33-31-30-28-26-24-26-92-89-9096-117; antennal ratio 1.74-1.98 (average $1.84, \mathrm{n}=12$ ). Palpus yellowish brown, segments 4-5 produced beyond mandibular teeth, third segment with few subapical sensilla on inner margin; palpal ratio 2.10-2.80 (average $2.45, \mathrm{n}=18$ ). Mandible with 5 teeth.

Thorax. Scutum dark brown except prescutellar depression yellowish brown, anterior spine short; scutellum yellowish brown. Legs (Fig. 3) yellowish brown, midfemur and distal $1 / 4$ of hind tibia dark brown, hind femur infuscate dorsally; tarsi (Fig. 4) dark brown, except tarsomere 1 and basal $1 / 2$ of tarsomere 2 of hind leg and basal $1 / 2$ of tarsomere 1 of hind leg yellowish brown. Wing (Figs. 2, 9) length 3.00-3.77 (average $3.38, \mathrm{n}=19$ ) $\mathrm{mm}$, width $0.80-1.00$ (average $0.87, \mathrm{n}=19$ ) $\mathrm{mm}$; membrane whitish hyaline, infuscated at apex; anterior veins pale except $\mathrm{r}-\mathrm{m}$ crossvein and $\mathrm{R}_{2}$ pale brown, apical portion of $\mathrm{M}_{1}, \mathrm{M}_{2}, \mathrm{MCu}_{1}, \mathrm{MCu}_{2}$ slightly infuscate; anal angle strongly developed, forming an angle of nearly $90^{\circ}$; costal ratio 0.89-0.92 (average 0.90, $\mathrm{n}=19$ ). Halter dark brown.

Abdomen. Brown. Five pairs of gland rods. Spermatheca (Fig. 5) well sclerotized, ovoid with well developed slender neck, measuring 95 by $73 \mu \mathrm{m}$, neck $15 \mu \mathrm{m}$.

Male. Similar to female with usual sexual differences. Flagellum dark brown, proximal flagellomeres slightly paler; all flagellomeres lacking black hastate setae. Hind femur entirely dark brown. Wing (Fig. 6) length 1.38-1.47 (average $1.45, \mathrm{n}=3$ ) $\mathrm{mm}$; width 0.41-047 (average $0.44, \mathrm{n}=3$ ) $\mathrm{mm}$; anterior veins brown, membrane without apical infuscation, anal angle not developed, costal ratio 0.77-0.82 (average $0.79, \mathrm{n}=3$ ). Genitalia (Fig. 7): tergite 9 short, not reaching level of apex of gonocoxite, cercus elongate, slender; sternite 90.33 times longer than broad, distal margin irregular, not excavated. Gonocoxite stout, inner margin tapering; gonostylus 0.70 times longer than gonocoxite, slender, deeply curved with pointed tip. Parameres (Fig. 8) narrowly fused basally, contiguous distally. Aedeagus triangular; basal arms slender, well sclerotized; basal arch very high; tip lightly sclerotized, papilliform.

\section{Taxonomic summary}

Distribution. Known only from the type-locality. Types. Holotype female, Peru, Cuzco prov., Pagoreni, $11^{\circ}$ 42' 21.9" S, 72 54' 21.9" W, VII-2004, J. Williams, at light; allotype male, Cuzco prov., Kirigueti, $11^{\circ} 38^{\prime} 13^{\prime \prime}$ S, $73^{\circ} 07^{\prime} 07^{\prime \prime} \mathrm{W}, \mathrm{VII}-2004$, J. Williams, at light. Other paratypes, 18 females, 2 males, as follows: same data as holotype, 7 females; same data as allotype, 11 females, 2 males.

\section{Remarks}

Paryphoconus anomalicornis Kieffer is the only species that shares the peculiar coloration and setation of the female antenna with $P$. peruvianus, but the distal flagellomeres in the former are distinctly shorter. The main character to distinguish both species is the very narrow anal angle of the wing in $P$. anomalicornis, which is broad, well developed in the new species, as well as the strong wing infuscation in P. anomalicornis, not only on the membrane but also on the anterior veins and along the posterior ones. The wing photos of both species (Figs. 9-10) clearly illustrate these features.

\section{Paryphoconus anomalicornis Kieffer}

Paryphoconus anomalicornis Kieffer, 1917: 333 (female; Colombia, and Paraguay); Wirth and Ratanaworabhan, 1972: 1372 (redescr.; distrib.); Spinelli and Wirth, 1984: 889 (notes; wing photo); Borkent and Wirth, 1997: 136 (in World catalog); Spinelli, 1998: 51 (Argentina record); Borkent and Spinelli, 2000: 65 (in catalog south of USA); Borkent and Spinelli, 2007: 97 (Neotropical cat.).

\section{Taxonomic summary}

Previous distribution. Mexico to Colombia, Venezuela, Brazil (Amazonas), Paraguay, and northeastern Argentina. New record. Peru, Cuzco prov., Pagoreni, $11^{\circ} 42^{\prime} 21.9^{\prime \prime}$ S, $72^{\circ} 54^{\prime} 21.9^{\prime}$ W, VII-2004, J. Williams, 1 female, at lights.

Paryphoconus fusciradialis Spinelli and Wirth

Paryphoconus fusciradialis Spinelli and Wirth, 1984: 895 (female; Brazil; wing photo); Borkent and Wirth, 1997: 136 (in World catalog); Borkent and Spinelli, 2000: 65 (in catalog south of USA); Borkent and Spinelli, 2007: 98 (Neotropical cat.). 

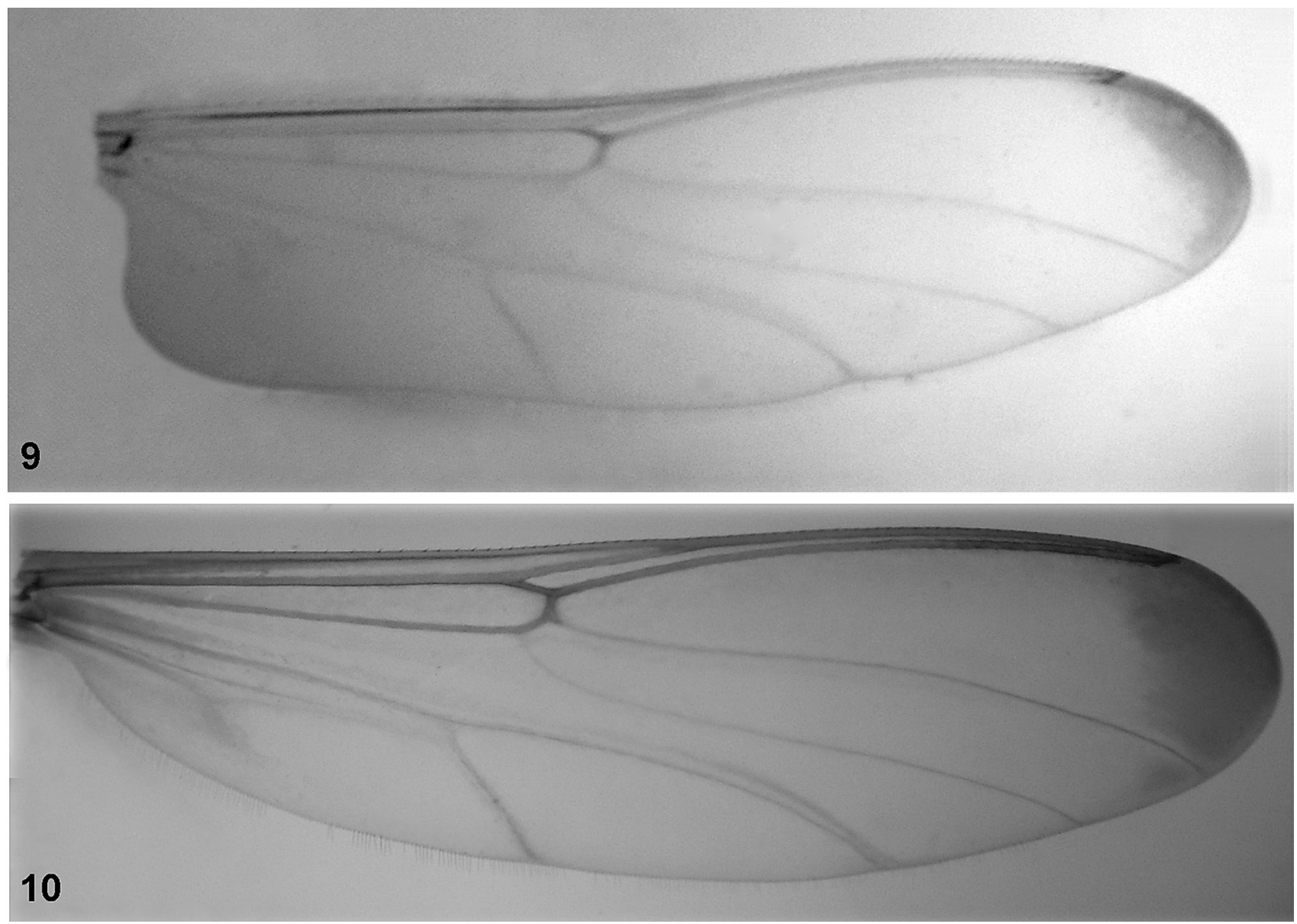

Figures 9-10. Wing photographs. 9, Paryphoconus peruvianus Mauad and Spinelli, female holotype; 10, Paryphoconus anomalicornis Kieffer, female.

\section{Taxonomic summary}

Previous distribution. Brazil (Pará).

New record. Peru, Iquitos, Casa de Juan, 13-VIII-1996, R. Fernández, 1 female, CDC light trap.

\section{Paryphoconus oliveirai Lane}

Paryphoconus oliveirai Lane, 1956: 303 (female; Brazil); Wirth and Ratanaworabhan, 1972: 1374 (female redescr.; pupa); Spinelli and Wirth, 1984: 889 (Colombia record; wing photo); Borkent and Wirth, 1997: 136 (World cat.); Borkent and Spinelli, 2000: 66 (cat. south of USA); Borkent and Spinelli, 2007: 98 (Neotropical cat.); Ronderos et al., 2007: 363 (redescr. pupa).

\section{Taxonomic summary}

Previous distribution. Colombia, Brazil (Amazonas and Pará).

New record. Peru, Cuzco prov., Pagoreni, $11^{\circ}$ 42' 21.9" S, 72 ${ }^{\circ}$ 54' 21.9" W, VII-2004, J. Williams, 2 females, at light; Cuzco prov., Kirigueti, $11^{\circ} 38^{\prime} 13^{\prime \prime} \mathrm{S}, 73^{\circ} 07^{\prime} 07^{\prime \prime} \mathrm{W}$, VII-2004, J. Williams, 3 females, at light; Cuzco prov., San Martín, $11^{\circ} 46^{\prime} 17^{\prime}$ S, 72 4' 52.6” W , 458 m, 14-II-2006, J. Williams, 1 female, at light.

\section{Acknowledgments}

We gratefully acknowledge Pluspetrol Peru Corporation S.A. and ERM Peru S.A. for the financial support of the 
fieldwork, which was carried out during the environmental impact assessment of block 56. Our gratitude also goes to Jorge D. Williams for his continuous effort in collecting ceratopogonids.

\section{Literature cited}

Borkent, A. and G. R. Spinelli. 2000. Catalog of the New World biting midges south of the United States of America (Diptera: Ceratopogonidae). Contributions on Entomology, International 4:1-107.

Borkent, A. and G. R. Spinelli. 2007. Neotropical Ceratopogonidae (Diptera: Insecta). In Aquatic biodiversity in Latin America (ABLA), J. Adis, J. R. Arias, G. Rueda-Delgado and K. M. Wnatzen (eds.). Vol. 4. Pensoft, Sofia-Moscow. p. 198.

Borkent, A. and W. W. Wirth. 1997. World species of biting midges (Diptera: Ceratopogonidae). Bulletin of the American Museum of Natural History 233:1-257.

Kieffer, J. J. 1917. Chironomides d'Amérique conservés au Musée National Hongrois de Budapest. Annales HistoricoNaturales Musei Nationalis Hungarici 15: 292-364.

Lane, J. 1956. On "Paryphoconous» and Stenoxenus (Diptera,
Ceratopogonidae). Revista Brasileira de Biologia 16:299-308.

McAlpine, J., B. Peterson, G. E. Shewell, H. J. Teskey, J. R. Vockeroth and D. M. Wood (coords). 1981. In Manual of Nearctic Diptera, Vol. 1, Agriculture Canada Monograph 27. p. 674 .

Ronderos, M. M., G. R. Spinelli and D. Silveira Carrasco. 2007. Redescription of the pupa of Paryphoconus oliveirai Lane (Diptera Ceratopogonidae) from Brazil. Entomological News 118:361-365.

Spinelli, G. R. 1998. Three new species and new records on Neotropical Stenoxenini (Diptera: Ceratopogonidae). Neotropica 44:51-55.

Spinelli, G. R. and W. W. Wirth. 1984. A review of the Neotropical midge genus Paryphoconus (Diptera: Ceratopogonidae). Proceedings of the Biological Society of Washington 97:882-908.

Szadziewski, R.1996. Biting midges from Lower Cretaceous amber of Lebanon and Upper Cretaceous Siberian amber of Taimyr (Diptera: Ceratopogonidae). Studia Dipterologica 3:23-86.

Wirth, W. W and N. C. Ratanaworabhan. 1972. A revision of the tribe Stenoxenini (Diptera: Ceratopogonidae). Annals of the Entomological Society of America 64:1368-1388. 
